Sains Malaysiana 49(5)(2020): 979-988

http://dx.doi.org/10.17576/jsm-2020-4905-02

\title{
Simple and Sensitive Electrokinetic Supercharging in Capillary Electrophoresis for Online Preconcentration and Separation of Secbumeton in Water Samples
}

(Superpengesan Elektrokinetik Ringkas dan Sensitif dalam Elektroforesis Rerambut Prapemerkatan secaraTerus dan Permisahan Sekbumeton dalam Sampel Air)

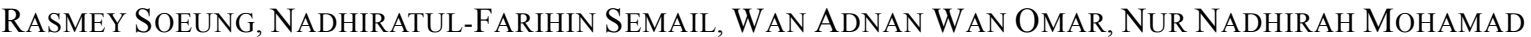 \\ Zain, Mazidatulakmam Miskam, Yong Foo Wong, Aemi SyazWani Abdul Keyon, Muggundha Raoov \\ RAMACHANDRAN, SAZLINDA KAMARUZAMAN \& NOORFATIMAH YAHAYA*
}

\begin{abstract}
This study describes an electrokinetic supercharging for online preconcentration capillary electrophoresis (CE) technique of secbumeton in water samples. Important CE separation and preconcentration conditions, such as concentration and $\mathrm{pH}$ of the background electrolyte, applied voltage and ultraviolet wavelength, type and injection time of the terminating electrolyte, and injection time of the leading electrolyte and sample were investigated and optimized. The optimum conditions involved hydrodynamic injection of leading electrolyte (100 mM sodium chloride, $30 \mathrm{~s}, 50 \mathrm{mbar}$ ), electrokinetic injection of the sample as high as $250 \mathrm{~s}$ (at $+7 \mathrm{kV}$ voltage), and hydrodynamic injection of terminating electrolyte (100 mM Tris buffer, $40 \mathrm{~s}, 50 \mathrm{mbar}$ ). This strategy enhanced secbumeton detection sensitivity up to 3847 -fold and 2267-fold when compared with hydrodynamic and electrokinetic injection, respectively, providing a limit of detection as low as $0.03 \mu \mathrm{g} L^{-1}$ with good repeatability (relative standard deviation $\left.<4 \%, n=5\right)$. Wide linear range $(0.1-500 \mu g$ $\left.L^{-1}\right)$ with good linearity $\left(R^{2}=0.9997\right)$ was obtained. The limit of detection was adequate for the analysis of secbumeton in water samples with concentrations lower than its maximum residual limit $\left(0.1 \mu \mathrm{g} \mathrm{L}^{-1}\right)$. The developed method was applied to environmental water samples, and recoveries were between 85.7 and $105.6 \%$.
\end{abstract}

Keywords: Capillary electrophoresis; electrokinetic supercharging; environmental water samples; online preconcentration; secbumeton

\section{ABSTRAK}

Kajian ini menerangkan suatu superpengecasan elektrokinetik bagi prapemekatan secara terus teknik elektroforesis rerambut (CE) bagi sekbumeton di dalam sampel air. Pemisahan CE dan keadaan prapemekatan yang penting seperti kepekatan dan pH bagi latar belakang elektrolit, voltan gunaan dan panjang gelombang ultraviolet, jenis dan masa suntikan bagi elektrolit penamat dan masa suntikan bagi elektrolit pemula dan sampel telah dikaji dan dioptimumkan. Keadaan optimum termasuklah suntikan hidrodinamik bagi elektrolit pemula (100 mM natrium klorida, $30 \mathrm{~s}, 50 \mathrm{mbar}$ ), suntikan elektrokinetik bagi sampel setinggi $250 \mathrm{~s}$ (pada $+7 \mathrm{kV}$ voltan) dan suntikan hidrodinamik bagi elektrolit penamat (100 mM larutan penimbal TRIS, 40 s, 50 mbar). Strategi ini meningkatkan kepekaan penentuan sekbumeton sehingga 3847-gandaan dan 2267-gandaan apabila dibandingkan dengan masingmasing, suntikan hidrodinamik dan elektrokinetik, dengan memberi had pengesanan serendah $0.03 \mu \mathrm{g} L^{-1}$ dengan kebolehulangan yang baik (sisihan piawai relatif $<4 \%, n=5$ ). Julat linear yang besar $\left(0.1-500 \mu g L^{-1}\right)$ dengan kelinearan yang baik $\left(R^{2}=0.9997\right)$ telah diperoleh. Had pengesanan ini adalah mencukupi bagi menganalisa sekbumeton di dalam sampel air dengan kepekatan yang lebih rendah daripada had surih maksimum $\left(0.1 \mu g L^{-1}\right)$. Kaedah yang telah dibangunkan telah digunakan bagi sampel air sekitaran dan pengembalian adalah antara 85.7 dan $105.6 \%$.

Kata kunci: Elektroforesis rerambut; prapemekatan secara terus; sampel air sekitaran; sekbumeton; superpengecasan elektrokinetik

\section{INTRODUCTION}

Pesticides and herbicides are frequently used in humid regions and agricultural sites to provide high quality agricultural products. For instance, S-triazine pesticides have been applied all over the world to control weeds in forestry and industrial sites (Siripattanakul et al. 2009). Although soil bacteria have pesticide biodegradation properties, the amount of accidental exposure to pesticides experienced by ecosystems is increasing due to the intensive use making them more frequently detected in soil (Nousiainen et al. 2015). Moreover, heavy rainfall causes significant movement of herbicides into the drainage systems and run off, leading to flooding of chemical residues in surface water. Atrazine concentrations above the maximum residue limit (MRL) for drinking water have been frequently detected because of its high mobility and persistence in soil and its massive application to crops (Piutti et al. 2002; Sagarkar et al. 2013). The MRLs of various triazines established by the United States 
Environmental Protection Agency are between 1 and 4 $\mu \mathrm{g} \mathrm{L}^{-1}$ (Watershed Management Section 2016). Although atrazines were banned in October 2003 among different European countries, persistent pollutions of atrazine in surface-water and ground water systems have been frequently reported due to illegal applications of this pesticide in agriculture (Jablonowski et al. 2011).

Due to the long term and extensive use, the triazine pesticides have been found in many agricultural products (Li et al. 2017; Liang et al. 2018). Health issues, including dizziness, drowsiness, gastric, and intestinal issues, cracking or skin dryness, and corneal problems are caused by secbumeton (SEC) toxicity (Alvarsson 2012). This toxicant can spread to the environment and into aquatic organisms, including fish, algae, and bacteria, which could affect climate, and ecology (LeBaron et al. 2008). Monitoring of the influence of pesticide contamination on aquatic systems has been implemented in many parts of Europe, Japan, and America (Yamaguchi et al. 2003), in fact, in Canada, drinking water has the lowest acceptance level for triazine (i.e. $0.005 \mathrm{mg} \mathrm{L}^{-1}$ ) among all types of agriculture-based food products of concerns (Safe Environments Programme 2006). Therefore, a rapid, sensitive, accurate, and environmentally friendly method is required to monitor the concentrations of triazines in the environment.

Numerous methods have been developed to separate and detect triazines from samples, including high performance liquid chromatography with an ultraviolet detector (HPLC-UV) (Gao et al. 2012; Liu et al. 2014; Wang et al. 2012; Yang et al. 2014), HPLC with a diode array detector (DAD) (Rodríguez-González et al. 2014; Zhao et al. 2011), gas chromatography-mass spectrometry (GCMS) (Sanagi et al. 2012), liquid chromatography-mass spectrometry (LC-MS) (Ji et al. 2008), and micro-LC with UV-Vis detector (See et al. 2010). These methods are relatively less green and time consuming, as most require off-line extraction and a large volume of organic solvents as extractant (i.e. liquid-liquid extraction and solid-phase extraction) (Acedo-Valenzuela et al. 2004). As an alternative, utilizing capillary electrophoresis (CE) system due to its ability in online preconcentration prior to separation. One of the preconcentration techniques that has been developed can provide high sensitivity without a significant increase in sample-to sample time is termed electrokinetic supercharging (EKS) (Hirokawa et al. 2003).
EKS is the combination of field-amplified sample injection (FASI) and transient isotachophoresis (tITP) was introduced by Hirokawa in 2003. In comparison to the conventional hydrodynamic injection where all solution is introduced under pressure to the capillary, electrokinetic injection is preferable used only for charged species. Those selected species are introduced based on their electrophoretic mobility in to the capillary. When the injection proceeds under co-electroosmotic flow conditions, apparent mobilities should be taken into account (Khaledi 1998). This technique has been shown to have excellent preconcentration efficiency when used to detect non-steroidal inflammatory drugs, paraquat and sedative drugs in samples (Botello et al. 2013; Dawod et al. 2008; Qi et al. 2017). Enhancement factors up four orders of magnitude have been reported in the literature (Abdul Karim et al. 2016; Botello et al. 2013; Dawod et al. 2009; Lu et al. 2014; Wen et al. 2010). Thus, this technique overcomes the shortcoming of low sensitivity.

Thus, the aim of this study was to develop a simple and sensitive electrokinetic supercharging capillary zone electrophoresis (EKS-CZE) method for the online preconcentration and separation of SEC in selected environmental water samples. To the best of our knowledge, this is the first report of the use of EKS for SEC analysis in environmental waters samples.

\section{MATERIALS AND METHODS}

The SEC standard (purity $\geq 97 \%$ ) and Trizma base (Tris) used in this study were purchased from Sigma-Aldrich, Co., (St. Louis, MO, USA) (Figure 1). HPLC-grade methanol was obtained from Friendemann Schmidt Chemical (Parkwood, WA, Australia). Sodium chloride $(\mathrm{NaCl})$ and sodium hydroxide $(\mathrm{NaOH})$ were purchased from R\&M Chemicals (Essex, UK). Formic acid was purchased from QRëC (ASIA) Sdn. Bhd. (Selangor, Malaysia). Milli-Q water used for stock and standard preparation was produced using a Sartorius Milli-Q water deionization system (Molsheim, France) with resistivity of $18.2 \mathrm{M} \Omega \mathrm{cm}^{-1}$. Standard solution of SEC $\left(1000 \mathrm{mg} \mathrm{L}^{-1}\right)$ was prepared in methanol and stored in the dark at 20 ${ }^{\circ} \mathrm{C}$. Standard mixtures of working solutions of SEC were prepared from appropriate dilutions of the stock made with deionized water. All other reagents were of analytical grade and used without any further purification.

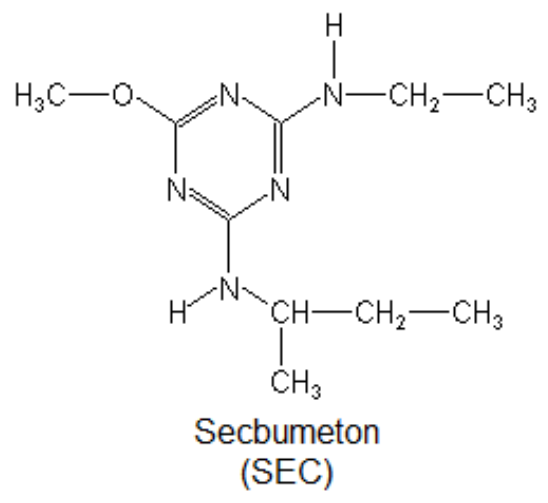

FIGURE 1. Chemical structure of SEC 


\section{INSTRUMENTATION AND CE CONDITIONS}

Electrophoretic separation was carried out on an Agilent CE 7100 device (Agilent Technologies, Santa Clara, CA, USA) coupled to a UV-DAD system. A bare fusedsilica capillary of $50 \mu \mathrm{m}$ I.D. with total and effective lengths of 65 and $56 \mathrm{~cm}$, respectively, was used (Agilent Technologies). Electrophoretic data were processed using ChemStation software (Agilent Technologies). New capillaries were preconditioned by flushing with $1 \mathrm{M}$ $\mathrm{NaOH}$ for $20 \mathrm{~min}, 0.1 \mathrm{M} \mathrm{NaOH}$ for $15 \mathrm{~min}$, and deionized water for $10 \mathrm{~min}$. After each separation, the capillary was rinsed with $0.1 \mathrm{M} \mathrm{NaOH}$ for $5 \mathrm{~min}$, deionized water for $5 \mathrm{~min}$, and background electrolyte (BGE) for $15 \mathrm{~min}$ to maintain the repeatability of the analysis. The BGE was adopted from previously reported work (Arribas et al. 2011) with slight modifications. It consisted of 100 $\mathrm{mM}$ formic acid solution adjusted to $\mathrm{pH}$ of 2.5 with 1 $\mathrm{M} \mathrm{NaOH}$. The BGE was freshly prepared daily prior to analysis to avoid any possible degradation of formic acid. A typical hydrodynamic injection (HDI) procedure was performed at 50 mbar for $10 \mathrm{~s}$. For FASI, a voltage of +5 $\mathrm{kV}$ and an injection time of $10 \mathrm{~s}$ were applied after filling the capillary with BGE.

\section{ELECTROKINETIC SUPERCHARGING CAPILLARY ZONE} ELECTROPHORESIS PROCEDURE

EKS was carried out by first filling the capillary with BGE followed by a short plug of $100 \mathrm{mM} \mathrm{NaCl}$, which functioned as the leading electrolyte (LE). The LE was hydrodynamically injected at 50 mbar for $30 \mathrm{~s}$. Next, the sample solution containing the analyte was injected at $+7 \mathrm{kV}$ for $250 \mathrm{~s}$. Lastly, $100 \mathrm{mM}$ Tris as the terminating electrolyte (TE) was injected hydrodynamically at 50 mbar for $40 \mathrm{~s}$. A voltage of $+25 \mathrm{kV}$ was applied to restack the diffuse band of injected analyte between LE and $\mathrm{TE}$, followed by a CZE separation.

\section{PREPARATION OF WATER SAMPLES}

Pond water was collected from a pond near the Advanced Medical and Dental Institute, Universiti Sains Malaysia, Pulau Pinang, Malaysia. River water was obtained from Kepala Batas, Pulau Pinang, Malaysia. All samples were stored in Schott bottles and transferred to the laboratory. Prior to analysis, each water sample was filtered through a $0.45 \mu \mathrm{m}$ nylon filter membrane. The samples were kept in the refrigerator at $4{ }^{\circ} \mathrm{C}$ to avoid for sample preservation.

\section{RESULTS AND DISCUSSION}

OPTIMIZATION OF ELECTROKINETIC SUPERCHARGING CAPILLARY ZONE ELECTROPHORESIS PARAMETERS

The hydrodynamic injection capillary zone electrophoresis (HDI-CZE) system was firstly optimized prior to the development of EKS-CZE. Several important parameters affecting the sensitivity of the system to Secbumeton (SEC) as the model analyte for atrazine herbicides were investigated, including the optimum UV wavelength, selection of BGE, $\mathrm{pH}$ and concentration of BGE, separation voltage and injection time. All optimization experiments were carried out in triplicate using deionized water spiked with $20 \mathrm{mg} \mathrm{L}^{-1}$ of SEC.

\section{EFFECTS OF UV WAVELENGTH, TYPE OF BACKGROUND ELECTROLYTE, AND BACKGROUND ELECTROLYTE PH ON THE CAPILLARY ZONE ELECTROPHORESIS SEPARATION OF SECBUMETON}

The optimum UV wavelength within the range of 200 to $260 \mathrm{~nm}$ was obtained at $214 \mathrm{~nm}$ by a scanning UV/VIS spectrophotometer. This wavelength provided the highest sensitivity and the best peak area and peak height of SEC with an acceptable percentage relative standard deviation $(\%$ RSD $<3 \%)$. The buffer used for CE separation can be prepared from several types of electrolytes. Formate, acetate, and phosphate are frequently used as low $\mathrm{pH}$ buffers (Arribas et al. 2011; Yan et al. 2003). SEC is a weak base with $p K_{a} \sim 4.4$, thus it will be positively charged when present in an acidic medium. Therefore, a buffer with $\mathrm{pH}<4.4$ was needed as the BGE for this study; sodium phosphate at $\mathrm{pH} 2$, sodium acetate at $\mathrm{pH}$ 4 , and sodium formate at $\mathrm{pH} 2.5$ were tested. Sodium formate at $\mathrm{pH} 2.5$ was found to be the most suitable BGE, with acceptable repeatability (RSD $<4 \% ; n=5$ ) and low background noise. This was in accordance with work by Arribas et al. (2011) that found formate buffer provided optimal resolution and efficiency and a moderate analysis time for the same group of pesticide (i.e. atrazine).

In $\mathrm{CE}$ separation, the most important parameter is the $\mathrm{pH}$ of $\mathrm{BGE}$ because it controls the direction and magnitude of electroosmotic flow (EOF), influences the charge of the compound, and affects the current and production of heat (Weinberger 2000). In this study, the effect of BGE $\mathrm{pH}$ on the separation of SEC was investigated under different $\mathrm{pH}$ values of sodium formate ranging from 2.5 to 4 (the $p K_{a}$ of formic acid was 3.75) (Reutemann et al. 2011). The highest peak area was obtained at $\mathrm{pH} 4(5.3 \mathrm{mAU})$ and the lowest at $\mathrm{pH} 2.5$ (3.2 mAU). The results indicated that higher $\mathrm{pH}$ value $(\mathrm{pH} 4)$ produced highest peak area due to broadening effect. However, pH 2.5 resulted in the fastest analysis time $(2.5 \mathrm{~min})$, and reproducibility at $\mathrm{pH} 2.5$ was also the lowest $(<6 \%)$. SEC was not further resolved at $\mathrm{pH}>$ 2.5 , but instead only migrated with the EOF with a broad peak. In contrast, more acidic $\mathrm{pH}$ increased SEC mobility as it became positively charged. Based on these results, the most suitable separation electrolyte with optimal resolution, highest peak height, and shortest migration time was $100 \mathrm{mM}$ sodium formate at $\mathrm{pH} 2.5(25 \mathrm{kV}$ separation voltage).

This result indicated that higher $\mathrm{pH}$ value may provide highest peak area as well as peak height. However, pH 2.5 gave the lowest migration time compared to other pHs, and RSD of $\mathrm{pH} 2.5$ was also the lowest and satisfactory (RSD < 6). Moreover, the EOF appeared at minimum time at $\mathrm{pH} 3$ up to 4 which may result in 
overlapping peaks due to peak broadening of SEC and EOF in further optimization. Thus, the electroosmotic mobility was strongly raised at higher $\mathrm{pH}$ value of the buffer and extremely low at the acidic ranges.

\section{EFFECTS OF BACKGROUND ELECTROLYTE}

CONCENTRATION, APPLIED VOLTAGE, AND INJECTION TIME ON THE CAPILLARY ZONE ELECTROPHORESIS SEPARATION

\section{OF SECBUMETON}

Another parameter that significantly influences CE separation and detection is the BGE concentration. Therefore, the effect of BGE concentration ranging from 80 to $120 \mathrm{mM}$ (fixed at $\mathrm{pH} 2.5$ ) were tested on CZE of SEC. As a result, the migration time and peak area increased gradually from the lowest to the high concentration (80-
$100 \mathrm{mM}$ ), however, no significant enhancement was observed beyond $100 \mathrm{mM}$ (Figure 2(a)). By considering the highest peak area with acceptable migration time $(<6 \mathrm{~min})$ of SEC and \%RSD $<3 \%, 100 \mathrm{Mm}$ formate buffer was chosen as the optimum BGE concentration for subsequent experiments. Additionally, several previous studies reported that buffer concentrations higher than $100 \mathrm{mM}$ were associated with the current and contributed to the Joule heating phenomenon (Arribas et al. 2011). The capacity of the capillary thermostatted system at higher separation voltage may be overwhelmed by the higher buffer concentration. Moreover, the stability of the analyte may be affected by this extreme Joule heating (Grossman 1992). Therefore, higher BGE concentration $(>100 \mathrm{mM})$ not used in this study.
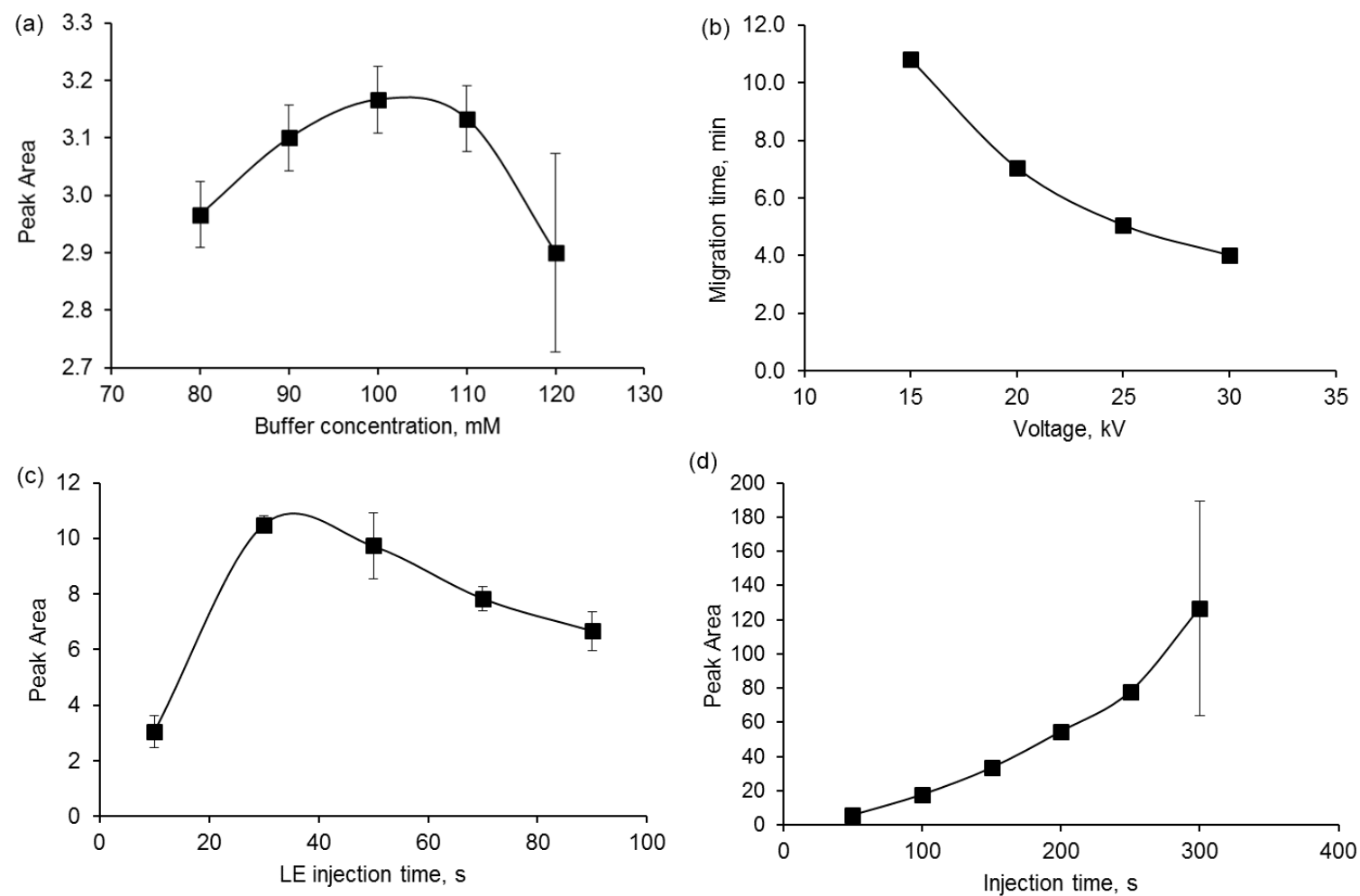

FIGURE 1. Effects of (a) BGE concentration, (b) applied voltage, (c) LE injection time and (d) EKS injection time on EKS-CZE separation of SEC. CZE conditions: capillary $65 \mathrm{~cm} \times 50 \mu \mathrm{m}$ i.d.; BGE $100 \mathrm{mM}$ formate at pH 2.5 , separation at $25^{\circ} \mathrm{C}$ and $25 \mathrm{kV}$; analytes mixture was injected at $7 \mathrm{kV}$ for $250 \mathrm{~s}$. UV detection at $214 \mathrm{~nm}$

Applied voltage is another parameter that is critical in CE optimization. Applied voltages ranging from +15 to $+30 \mathrm{kV}$ were investigated, and the shortest migration time of the analyte obtained when the highest voltage $(+30 \mathrm{kV})$ was applied, followed by $+25 \mathrm{kV}$ (Figure 2(b)). Solvent viscosity decreased with the rise in temperature, and because electrophoretic mobilities were inversely proportional to viscosity, this caused a decrease in viscosity of the BGE that led to higher mobilities as the voltage increased to $30 \mathrm{kV}$. However, in term of peak area, the lowest voltage used $(+15 \mathrm{kV})$ produces the highest peak area of SEC. Taking into consideration both migration time and peak area, $25 \mathrm{kV}$ was identified as the most suitable and optimum voltage for use in this study. Increasing applied voltage usually resulted in decreasing migration time of the analytes and increasing sharpness 
of the peak as well as enhancement of the resolution. However, increasing the applied voltage could also increase the speed of EOF, which could affect the peak of the analytes (Cazes 2010). Several investigations have shown that a low separation voltage resulted in prolonged migration time, and the peak of the analyte could not be resolved at voltages $\leq 10 \mathrm{kV}$ (Landers 1998).

The last effective parameter of HDI-CZE is the sample injection time. In this study, the hydrodynamic injection times were varied from 1 to $10 \mathrm{~s}$. As the injection time increased, the peak area was also amplified. However, a slightly broad SEC peak was observed in the electropherogram at injection times $>$ $5 \mathrm{~s}$. Thus, $10 \mathrm{~s}$ was chosen as the maximum injection time for HDI-CZE. The LOD of SEC was calculated based on the optimum HDI-CZE method. Based on the results obtained, the LOD $\left(115.4 \mu \mathrm{g} \mathrm{L}^{-1}\right)$ in HDI-CZE mode was not adequate to reach the MRLs $\left(0.1 \mu \mathrm{g} \mathrm{L}^{-1}\right)$ of SEC in the environmental water samples. To address this problem, another alternative injection mode (EKI) was evaluated.

\section{OPTIMIZATION OF ELECTROKINETIC INJECTION CAPILLARY ZONE ELECTROPHORESIS}

Due to the lower sensitivity of the optimized HDICZE method, an EKI-CZE was further explored for the separation and preconcentration of SEC. The difference between HDI and EKI was that different injection mode was used to introduce the sample. HDI used pressure to introduce the sample into the capillary, whereas EKI used voltage. With the EKI injection mode, the sample could be injected from 1 to $90 \mathrm{~s}$ with the low applied voltage (1-10 kV) (Landers 1998).

For EKI-CZE mode optimization, injection time ranging from 1 to $40 \mathrm{~s}$ were tested at a constant injection voltage of $+5 \mathrm{kV}$. All other conditions were similar as the HDI-CZE conditions. The highest peak area was obtained from the highest applied injection time (40 s), and the lowest was obtained from the lowest applied injection time (1 s). However, a high \% RSD (33\%) was also obtained from the $40 \mathrm{~s}$ injection time, which indicated that this injection time was not stable and produced inconsistent peak area of SEC. Partial deterioration of peak shape was observed for $40 \mathrm{~s}$ long injections and $10 \mathrm{~s}$ was chosen as optimum as it produced an efficient separation of SEC. A further increment in sensitivity could be obtained by using longer EKI injection time, however, for such conditions, different instrumental setup (e.g. longer effective length of separation capillary) would be necessary to achieve sufficient separation efficiency of the large electrokinetically injected sample plugs (Pantůčková et al. 2015). Therefore, injection time of $10 \mathrm{~s}$ and voltage of $5 \mathrm{kV}$ were identified as the best conditions for the EKI-CZE.

In preliminary investigations, the higher EKI injection time produced a rather broad SEC peak, likely due to the higher concentration being injected. Therefore, a lower concentration of SEC $\left(500 \mu \mathrm{g} \mathrm{L}^{-1}\right)$ was injected in triplicate under the optimized conditions of EKI-CZE and HDI-CZE. The analyte was successfully detected in $<7$ min for both the HDI and EKI modes. EKI resulted in better sensitivity ( $\mathrm{LOD}=68 \mu \mathrm{g} \mathrm{L}^{-1}$ ) as compared to the HDI-CZE (LOD $\left.=115.4 \mu \mathrm{g} \mathrm{L}^{-1}\right)$. Therefore, the calculated enhancement factor of EKI-CZE was $\sim 1$.7-fold greater than that of HDI-CZE. At the end of the capillary, EKI regularly amplified the electric field and improved on the quantification of trace level amount by varying the injection time, and concentration of sample with different capillary internal diameter (Altria 1996). Thus, the analyte could enter the capillary per second due to mobilize and ions of the analytes were more improved.

Under optimized conditions, the highest enhancement factor obtained for SEC was 1.7 for the EKI-CZE system. This was not sufficient to detect concentrations of SEC lower than the reported MRL $\left(0.1 \mu \mathrm{g} \mathrm{L}^{-1}\right)$. Thus, an online pre-concentration method, viz. EKS-CZE was developed to further enhance the sensitivity and to obtain the lowest LOD that was sufficient to analyze SEC near the MRL value in water samples.

\section{OPTIMIZATION OF ELECTROKINETIC SUPERCHARGING CAPILLARY ZONE ELECTROPHORESIS}

EKS involves electrokinetically injecting the sample between leading and terminating ions. In EKS-CZE, the BGE was first added into the capillary, followed by hydrodynamically injecting a small amount of LE. Then, the target analyte was introduced into the capillary by EKI for a certain amount of injection time. Lastly, the capillary was filled with a small volume of TE and BGE by HDI (Hirokawa et al. 2003) This process caused the diffused band of SEC to be restacked according to isotachophoresis (ITP) principle. After the ITP step was disrupted, the analyte was separated by CZE ( $\mathrm{Lu}$ et al. 2014).

The LE, TE, and EKI time were the most important factors that affected the sensitivity of the EKS-CZE (Hirokawa et al. 2003). A co-ion with electrophoretic mobility higher than that of the analyte was chosen as the LE, whereas one with lower mobility was chosen as the TE. According to Wang and Chen (2009), the mobility of $\mathrm{Na}^{+}$ion $\left(51.9 \times 10-9 \mathrm{~m}^{2} \mathrm{v}^{-1} \mathrm{~s}^{-1}\right)$ was higher than that of many organic anions and SEC. Thus, $100 \mathrm{mM} \mathrm{NaCl}$ was chosen as the LE in this study. According to formula on mobility;

$$
\mu \mathrm{A}=\mu \mathrm{E}+\mu \mathrm{EOF}=(\mathrm{lL} / \mathrm{tV})(\text { Altria 1996) }
$$

The electrophoretic mobility of Tris $(0.15 \times 10-9$ $\left.\mathrm{m} 2 \mathrm{v}^{-1} \mathrm{~s}^{-1}\right)$ was lower than that of the effective mobility of the analyte $\left(18.79 \times 10-9 \mathrm{~m}^{2} \mathrm{v}^{-1} \mathrm{~s}^{-1}\right)$, thus $100 \mathrm{mM}$ Tris was chosen as the TE. Two main part in stacking process involved were LE and TE with different mobility injected using pressure first and electrokinetic injection assists in stacking (tITP) and the analyte forming band 
or concentrating and stack between LE and TE ions when separation voltage applied (Abdul Karim et al. 2016).

The influence of the LE injection time was investigated over the range of 10 to $90 \mathrm{~s}$ for injection of $100 \mathrm{mM} \mathrm{NaCl}$. LE was hydrodynamically injected into the capillary at 50 mbar. Increasing LE injection time from 10 to $30 \mathrm{~s}$ resulted in a significant increase of SEC peak area, but it decreased beyond $30 \mathrm{~s}$ (Figure 2(c)). Thus, $30 \mathrm{~s}$ was chosen as the best LE injection time. Other recent studies of the separation of pollutants by EKS also demonstrated that $30 \mathrm{~s}$ was the optimum injection time for LE (Abdul Karim et al. 2016; Lu et al. 2014). In the TE optimization step, $100 \mathrm{mM}$ Tris was injected hydrodynamically at 50 mbar at injection times of $20 \mathrm{~s}(21 \mathrm{~nL}), 40 \mathrm{~s}(41 \mathrm{~nL})$, and $60 \mathrm{~s}(60 \mathrm{~nL})$. Injection time of $40 \mathrm{~s}$ was optimal for the system, as it produced the highest peak area among the times tested. Previous studies (Abdul Karim et al. 2016; Dawod et al. 2008) reported that among TE injection times ranging from $10 \mathrm{~s}$ to $100 \mathrm{~s}$, the optimum TE injection time was $40 \mathrm{~s}$ (approximately $2.7 \%$ of capillary volume). Thus, $40 \mathrm{~s}$ was used as TE injection time for subsequent experiments.
The final EKS-CZE parameter optimized was sample injection time, with times ranging from 50 to $300 \mathrm{~s}$. Increasing the injection time resulted in increasing peak area (Figure 2(d)). The highest peak area was obtained at $300 \mathrm{~s}$, but the repeatability was not poor (RSD of 50\%). EKS-CZE electropherogram showed that the peak area of the analyte became slightly broad when injection time increased to $300 \mathrm{~s}$. Thus, sample injection time of $250 \mathrm{~s}$ at $+7 \mathrm{kV}$ was chosen as the best injection time for further SEC analysis. In summary, the optimum conditions for EKS-CZE were as follows: HDI of LE $(100 \mathrm{mM} \mathrm{NaCl})$ and TE (100 mM Tris) at 50 mbar for $30 \mathrm{~s}$ and $40 \mathrm{~s}$, respectively, together with sample EKI at $+7 \mathrm{kV}$ for 250 $\mathrm{s}$. These conditions were expected to achieve LOD values lower than the MRL and high peak area with acceptable migration time. Other optimized conditions included BGE of $100 \mathrm{mM}$ sodium formate at $\mathrm{pH} 2.5$, wavelength $214 \mathrm{~nm}$, and applied voltage of $25 \mathrm{kV}$. The analyte was successfully preconcentrated and separated in $<10 \mathrm{~min}$ by applying these conditions. Electropherograms of SEC were compared among HDI-CZE, EKI-CZE, and EKS-CZE, and the SEC peak was significantly improved under the EKS-CZE system as compared to the others (Figure 3(a)).

(a)

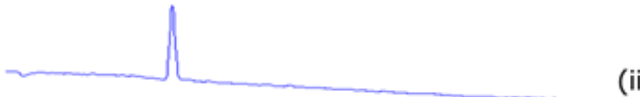

(ii)
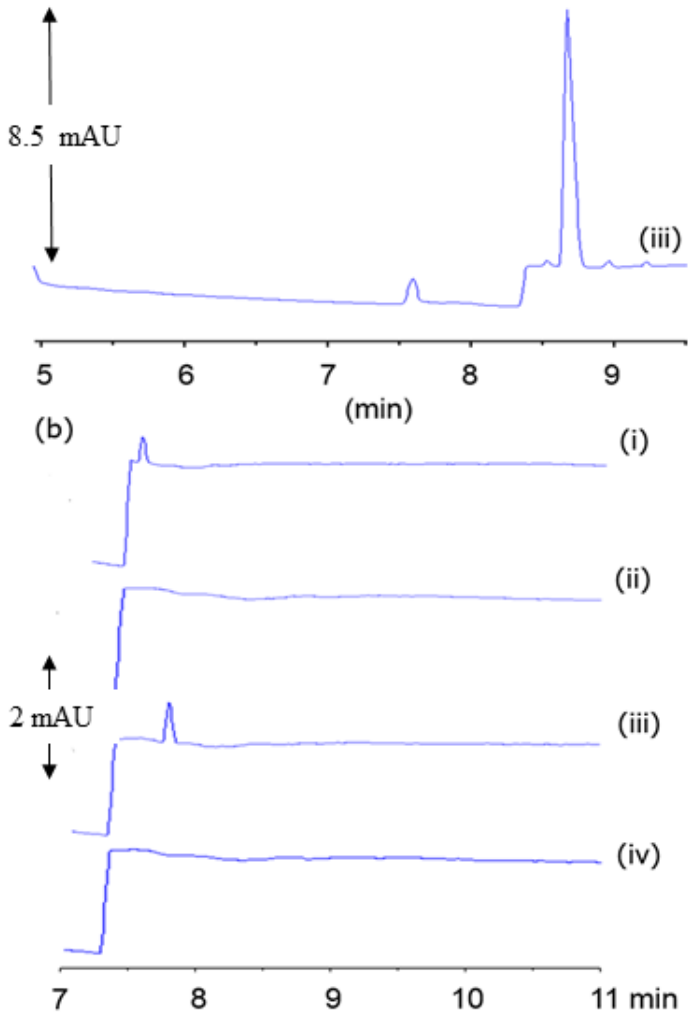

FIGURE 1. (a) Electropherograms of $500 \mu \mathrm{g} \mathrm{L} \mathrm{L}^{-1}$ SEC which were analyzed by HDI-CZE (i), EKI-CZE (ii), and EKS-CZE (iii). CE conditions as in Figure 2, (b) Electropherograms of the unspiked pond water (i), spiked pond water (100 $\mu \mathrm{g} \mathrm{L}^{-1} \mathrm{SEC}$ ) (ii), unspiked river water (iii), spiked river water (100 $\mu \mathrm{g} \mathrm{L}^{-1} \mathrm{SEC}$ ) (iv) samples. CE condition as in Figure 2 


\section{METHOD VALIDATION}

Under optimized EKS-CZE conditions, the method was validated in terms of linearity, LOD, LOQ, repeatability, and recovery. A matrix-matched calibration curve was obtained from the corresponding peak areas over eightpoints of concentrations of spiked pond water samples. The proposed method provided good linearity in the range of 0.1 to $500 \mu \mathrm{g} \mathrm{L}^{-1}$ with a good coefficient of determination $\left(R^{2}=0.9997\right)$ (Table 1$)$. The enhancement factor was calculated based on the LOD values obtained for EKS-CZE, HDI-CZE, and EKI-CZE. The LOD and LOQ were calculated based on a signal to noise ratio of three and ten, respectively. The obtained LOD for SEC was $0.03 \mu \mathrm{g} \mathrm{L}^{-1}$, which is below its MRL. The enhancement factor obtained by the EKS-CZE method was extremely high compared to that of the HDI-CZE (3847-fold) and EKI-CZE (2267-fold) methods (Table 1). Intra-day and inter-day repeatability (or precision) of the method was studied using two concentrations (low and high) from the calibration curve $\left(10\right.$ and $\left.100 \mu \mathrm{g} \mathrm{L}^{-1}\right)$. For the intra-day analysis, these two concentrations were analyzed over five independent series on the same day. For the interday analysis, the two concentrations were analyzed over five different days. All samples were injected in triplicate. The results were expressed as the percentage of RSD of the peak area and migration time (Table 2(a)). Good repeatability was obtained for SEC with RSD $<4 \%$ for both migration time and peak area.

TABLE 1. LOD, LOQ, enhancement factors (EFs), regression equation in EKS-CZE

\begin{tabular}{cccccccc}
\hline Analyte & $\begin{array}{c}\mathrm{LOD}^{\mathrm{a}} \\
\left(\mu \mathrm{g} \mathrm{L}^{-1}\right)\end{array}$ & $\begin{array}{c}\mathrm{LOQ}^{\mathrm{b}} \\
\left(\mu \mathrm{g} \mathrm{L}^{-1}\right)\end{array}$ & $\mathrm{EF}^{\mathrm{c}}$ & $\mathrm{EF}^{\mathrm{d}}$ & Regression equation & $\begin{array}{c}\text { Coefficient of } \\
\text { determination } \\
\left(R^{2}\right)\end{array}$ & $\begin{array}{c}\text { Linear range } \\
\left(\mu \mathrm{g} \mathrm{L}^{-1}\right)\end{array}$ \\
\hline SEC & 0.03 & 0.10 & 3847 & 2267 & $Y=0.0336 X+0.2412$ & 0.9997 & $0.1-500$ \\
\hline
\end{tabular}

aBased on three times noise, bBased on ten times noise, cCompared to HDI, \& dCompared to EKI

TABLE 2. Precision and recovery of the developed EKS-CZE method

(a) Intra-day and inter-day precision of the EKS-CZE method

\begin{tabular}{|c|c|c|c|c|c|}
\hline \multirow{3}{*}{ Analyte } & \multirow{3}{*}{$\begin{array}{c}\text { Concentration } \\
\qquad\left(\mu \mathrm{g} \mathrm{L}^{-1}\right)\end{array}$} & \multicolumn{2}{|c|}{ Intra-day (RSD \%) } & \multicolumn{2}{|c|}{ Inter-day (RSD \%) } \\
\hline & & \multicolumn{2}{|c|}{$(n=5)$} & \multicolumn{2}{|c|}{$(n=5)$} \\
\hline & & Migration time & Peak area & Migration time & Peak area \\
\hline & 10 & 2 & 2.7 & 3.2 & 3.8 \\
\hline \multicolumn{6}{|l|}{ SEC } \\
\hline & 100 & 1.1 & 3.2 & 2.5 & 3.6 \\
\hline
\end{tabular}

(b) Results of water samples analysis and recovery

\begin{tabular}{cccccc}
\hline \multirow{2}{*}{ Analyte } & Spiked & \multicolumn{2}{c}{ Pond water } & \multicolumn{2}{c}{ River water } \\
\cline { 3 - 6 } & $\left(\mu \mathrm{g} \mathrm{L}^{-1}\right)$ & Recovery & RSD & Recovery & RSD \\
& 10 & 105.7 & 3.5 & 91.9 & $(\%)$ \\
\hline \multirow{2}{*}{ SEC } & 100 & 95.7 & 3.9 & & 2.6 \\
& & & & 85.8 & 4.7 \\
\hline
\end{tabular}




\section{APPLICATION TO REAL SAMPLES}

To test the applicability of the developed method, the technique was used to analyze SEC in river and pond water samples. Figure 3(b) shows the electropherograms of the unspiked and spiked (100 $\mu \mathrm{g} \mathrm{L}^{-1}$ SEC) samples. No SEC was detected in all blank samples, indicating that the samples were free from SEC contamination. For the recovery study, SEC was measured in water samples that had been spiked with 10 or $100 \mu \mathrm{g} \mathrm{L}^{-1}$ of SEC. Good recoveries ranging from 86 to $106 \%$ with acceptable RSD (<5\%) were obtained for SEC (Table 2(b)).

\section{CONCLUSION}

A new method for the analysis of SEC in environmental water samples by EKS-CZE was developed. The sensitivity improved by 3847 -fold, providing a detection limit of $0.03 \mu \mathrm{g} \mathrm{L}^{-1}$, which was lower than the MRLs established by the European Union Directive $\left(0.1 \mu \mathrm{g} \mathrm{L}^{-1}\right)$. The optimized EKS-CZE conditions were as follows: HDI of LE $(100 \mathrm{mM} \mathrm{NaCl})$ at $50 \mathrm{mbar}$ for $30 \mathrm{~s}$; EKI of sample at $7 \mathrm{kV}$ for $250 \mathrm{~s}$; HDI of TE (100 mM Tris) at 50 mbar for $40 \mathrm{~s} ; 25 \mathrm{kV}$ separation voltage; wavelength of $214 \mathrm{~nm}$; and BGE of $100 \mathrm{mM}$ formate at $\mathrm{pH} 2.5$. The developed method provided good linearity, acceptable repeatability, and satisfactory recovery. This method is inexpensive, environmentally friendly, rapid, and simple, and it was shown to be suitable for the detection and measurement of SEC in water samples. Overall, the developed method had great potential for routine monitoring of SEC and other compounds in environmental water samples.

\section{ACKNOWLEDGEMENTS}

The authors acknowledge the supports from the Ministry of Education Malaysia (Fundamental Research Grant Scheme - 203.CIPPT.6711630 and R.J130000.7854. 5F010) and Universiti Sains Malaysia Research Grant (Research University Grant - 1001/CIPPT/8011052).

\section{REFERENCES}

Abdul Karim, N.'I., Wan Ibrahim, W.A., Sanagi, M.M. \& Abdul Keyon, A.S. 2016. Online preconcentration by electrokinetic supercharging for separation of endocrine disrupting chemical and phenolic pollutants in water samples. Electrophoresis 37(20): 2649-2656.

Acedo-Valenzuela, M.I., Galeano-Díaz, T., Mora-Díez, N. \& Silva-Rodríguez, A. 2004. Determination of neutral and cationic herbicides in water by micellar electrokinetic capillary chromatography. Analytica Chimica Acta 519(1): 65-71.

Altria, K.D. 1996. Chapter 1. Fundamentals of capillary electrophoresis theory. In Capillary Electrophoresis Guidebook. Volume 52. Springer. pp. 3-13.
Alvarsson, A. 2012. Assessing the environmental impact of pesticides: Effects of photosystem ii inhibiting herbicides on primary production and ecosystems. Degree Project for Master of Science in Ecotoxicology 30 ECTS. Department of Biology and Environmental Sciences, University of Gothenburg, Sweden pp. 1-58. (Unpublished).

Arribas, A.S., Moreno, M., Bermejo, E., Zapardiel, A. \& Chicharro, M. 2011. CZE separation of amitrol and triazine herbicides in environmental water samples with acidassisted on-column preconcentration. Electrophoresis 32(2): 275-283.

Botello, I., Borrull, F., Calull, M. \& Aguilar, C. 2013. Electrokinetic supercharging in $\mathrm{CE}$ for the separation and preconcentration of barbiturate drugs in urine samples. Journal of Separation Science 36(3): 524-531.

Cazes, J. 2010. Encyclopedia of chromatography. Crop Science 2(6): 1419.

Dawod, M., Breadmore, M.C., Guijt, R.M. \& Haddad, P.R. 2008. Electrokinetic supercharging for on-line preconcentration of seven non-steroidal anti-inflammatory drugs in water samples. Journal of Chromatography A 1189(1-2): 278-284.

Dawod, M., Breadmore, M.C., Guijt, R.M. \& Haddad, P.R. 2009. Counter-flow electrokinetic supercharging for the determination of non-steroidal anti-inflammatory drugs in water samples. Journal of Chromatography A 1216(15): 3380-3386.

Gao, Y., Zhou, Q., Xie, G. \& Yao, Z. 2012. Temperaturecontrolled ionic liquid dispersive liquid-phase microextraction combined with HPLC with ultraviolet detector for the determination of fungicides. Journal of Separation Science 35(24): 3569-3574.

Grossman, P.D. 1992. Factors affecting the performance of capillary elecrophoresis separations: Joule heating, electroosmosis, and zone dispersion. In Capillary Electrophoresis: Theory and Practice, edited by Grossman, P.D. \& Colburn, J.C. Massachusetts: Academic Press. p. 352.

Hirokawa, T., Okamoto, H. \& Gaš, B. 2003. High-sensitive capillary zone electrophoresis analysis by electrokinetic injection with transient isotachophoretic preconcentration: Electrokinetic supercharging. Electrophoresis 24(3): 498504.

Jablonowski, N.D., Schäffer, A. \& Burauel, P. 2011. Still present after all these years: Persistence plus potential toxicity raise questions about the use of atrazine. Environmental Science and Pollution Research 18(2): 328-331.

Ji, F., Zhao, L., Yan, W., Feng, Q. \& Lin, J.M. 2008. Determination of triazine herbicides in fruits and vegetables using dispersive solid-phase extraction coupled with LCMS. Journal of Separation Science 31(6-7): 961-968.

Khaledi, M.G. 1998. High-performance capillary electrophoresis. Theory, techniques and applications. Chemical Analysis 146: 4930-4931.

Landers, J.P. 1998. Handbook of capillary electrophoresis. Journal of Liquid Chromatography \& Related Technologies 21(1-2): 263-266.

LeBaron, H.M., McFarland, J.E. \& Burnside, O.C. 2008. Chapter 1 - The Triazine Herbicides: A Milestone in the Development of Weed Control Technology. Volume 2016. Elsevier.

Li, X., Sun, Y., Sun, Q., Liang, L., Piao, H., Jiang, Y., Yu, A., Song, D. \& Wang, X. 2017. Ionic-liquid-functionalized 
zinc oxide nanoparticles for the solid-phase extraction of triazine herbicides in corn prior to high-performance liquid chromatography analysis. Journal of Separation Science 40(14): 2992-2998.

Liang, L., Wang, X., Sun, Y., Ma, P., Li, X., Piao, H., Jiang, Y. \& Song, D. 2018. Magnetic solid-phase extraction of triazine herbicides from rice using metal-organic framework mil101(cr) functionalized magnetic particles. Talanta 179(11): 512-519.

Liu, T., Cao, P., Geng, J., Li, J., Wang, M., Wanga, M., Li, X. \& Yin, D. 2014. Determination of triazine herbicides in milk by cloud point extraction and high-performance liquid chromatography. Food Chemistry 142: 358-364.

Lu, Y., Wang, D., Kong, C., Zhong, H. \& Breadmore, M.C. 2014. Analysis of aromatic acids by nonaqueous capillary electrophoresis with ionic-liquid electrolytes. Electrophoresis 35(23): 3310-3316.

Nousiainen, A.O., Björklöf, K., Sagarkar, S., Nielsen, J.L., Kapley, A. \& Jørgensen, K.S. 2015. Bioremediation strategies for removal of residual atrazine in the boreal groundwater zone. Applied Microbiology and Biotechnology 99(23): 10249-10259.

Pantůčková, P., Kubáň, P. \& Boček, P. 2015. Sensitivity enhancement in direct coupling of supported liquid membrane extractions to capillary electrophoresis by means of transient isotachophoresis and large electrokinetic injections. Journal of Chromatography A 1389: 1-7.

Piutti, S., Hallet, S., Rousseaux, S., Philippot, L., Soulas, G. \& Martin-Laurent, F. 2002. Accelerated mineralisation of atrazine in maize rhizosphere soil. Biology and Fertility of Soils 36(6): 434-441.

Qi, M., Yien, L. \& Heng, H. 2017. Integration of the free liquid membrane into electrokinetic superchargingcapillary electrophoresis for the determination of cationic herbicides in environmental water samples. Journal of Chromatography A 1481: 145-151.

Reutemann, W., Kieczka, H., Reutemann, W. \& Kieczka, H. 2011. Formic acid. Ullmann's Encyclopedia of Industrial Chemistry. pp. 1-22.

Rodríguez-González, N., González-Castro, M.J., BeceiroGonzález, E., Muniategui-Lorenzo, S. \& Prada-Rodríguez, D. 2014. Determination of triazine herbicides in seaweeds: Development of a sample preparation method based on matrix solid phase dispersion and solid phase extraction clean-up. Talanta 121: 194-198.

Safe Environments Programme. 2006. Guidelines for Canadian Drinking Water Quality: Guideline technical document: Trihalomethanes - Health Canada. 1993: 1-9.

Sagarkar, S., Mukherjee, S., Nousiainen, A., Björklöf, K., Purohit, H.J., Jorgensen, K.S. \& Kapley, A. 2013. Monitoring bioremediation of atrazine in soil microcosms using molecular tools. Environmental Pollution 172: 108115.

Sanagi, M.M., Abbas, H.H., Ibrahim, W.A.W. \& Aboul-Enien, H.Y. 2012. Dispersive liquid-liquid microextraction method based on solidification of floating organic droplet for the determination of triazine herbicides in water and sugarcane samples. Food Chemistry 133(2): 557-562.

See, H.H., Marsin Sanagi, M., Ibrahim, W.A.W. \& Naim, A.A. 2010. Determination of triazine herbicides using membraneprotected carbon nanotubes solid phase membrane tip extraction prior to micro-liquid chromatography. Journal of Chromatography A 1217(11): 1767-1772.
Siripattanakul, S., Wirojanagud, W., McEvoy, J., Limpiyakorn, T. \& Khan, E. 2009. Atrazine degradation by stable mixed cultures enriched from agricultural soil and their characterization. Journal of Applied Microbiology 106(3): 986-992.

Wang, H., Li, G., Zhang, Y., Chen, H., Zhao, Q., Song, W., $\mathrm{Xu}$, Y., Jin, H. \& Ding, L. 2012. Determination of triazine herbicides in cereals using dynamic microwave-assisted extraction with solidification of floating organic drop followed by high-performance liquid chromatography. Journal of Chromatography A 1233: 36-43.

Wang, X. \& Chen, Y. 2009. Determination of aromatic amines in food products and composite food packaging bags by capillary electrophoresis coupled with transient isotachophoretic stacking. Journal of Chromatography A 1216(43): 7324-7328.

Watershed Management Section. 2016. Water quality standards for surface waters of the state of washington chapter 173201a WAC. Water Quality Standards for Surface Waters of the State of Washington (6): 1-134.

Weinberger, R. 2000. Capillary zone electrophoresis: Methods development. In Practical Capillary Electrophoresis. 2nd ed. Massachusetts: Academic Press.

Wen, Y., Liu, H., Han, P., Gao, Y., Luan, F. \& Li, X. 2010. Determination of melamine in milk powder, milk and fish feed by capillary electrophoresis: A good alternative to HPLC. Journal of the Science of Food and Agriculture 90(13): 2178-2182.

Yamaguchi, N., Gazzard, D., Scholey, G. \& Macdonald, D.W. 2003. Concentrations and hazard assessment of pcbs, organochlorine pesticides and mercury in fish species from the upper thames: River pollution and its potential effects on top predators. Chemosphere 50(3): 265-273.

Yan, Y., Yu, J., Jiang, Y., Hu, Y., Cai, M., Hsam, S.L.K. \& Zeller, F.J. 2003. Capillary electrophoresis separation of high. Electrophoresis 24: 1429-1436.

Yang, X., Yu, R., Zhang, S., Cao, B., Liu, Z., Lei, L., Li, N., Wang, Z., Zhang, L., Zhang, H. \& Chen, Y. 2014. Aqueous two-phase extraction for determination of triazine herbicides in milk by high-performance liquid chromatography. Journal of Chromatography B: Analytical Technologies in the Biomedical and Life Sciences 972: 111-116.

Zhao, G., Song, S., Wang, C., Wu, Q. \& Wang, Z. 2011. Determination of triazine herbicides in environmental water samples by high-performance liquid chromatography using graphene-coated magnetic nanoparticles as adsorbent. Analytica Chimica Acta 708(1-2): 155-159.

Rasmey Soeung, Nadhiratul-Farihin Semail, Wan Adnan Wan Omar, Nur Nadhirah Mohamad Zain \& Noorfatimah Yahaya* Integrative Medicine Cluster

Advanced Medical and Dental Institute (AMDI)

Universiti Sains Malaysia

13200 Bertam Kepala Batas, Penang

Malaysia

Rasmey Soeung

Royal University of Agriculture

12400 Dangkor District

Phnom Penh

Cambodia 
Mazidatulakmam Miskam \& Yong Foo Wong

School of Chemical Sciences

Universiti Sains Malaysia

11800 Minden Penang

Malaysia

Aemi Syazwani Abdul Keyon

Department of Chemistry

Faculty of Science

Universiti Teknologi Malaysia

81310 UTM Johor Bahru, Johor Darul Takzim

Malaysia

Muggundha Raoov Ramachandran

Department of Chemistry, Faculty of Science

Universiti Malaya

50603 Kuala Lumpur, Federal Territory

Malaysia
Sazlinda Kamaruzaman

Department of Chemistry, Faculty of Science

Universiti Putra Malaysia

43400 UPM Serdang, Selangor Darul Ehsan

Malaysia

Aemi Syazwani Abdul Keyon

Centre for Sustainable Nanomaterials

Ibnu Sina Institute for Scientific and Industrial Research

Universiti Teknologi Malaysia

81310 Johor Bahru, Johor Darul Takzim

Malaysia

*Corresponding author; email: noorfatimah@usm.my

Received: 26 January 2019

Accepted: 19 January 2020 